\title{
Pengukuran Kualitas Layanan Website Terhadap Kepuasan Pengguna pada Universitas XYZ dengan Menggunakan Metode Webqual 4.0
}

\author{
Lisa Amelia', Iis Pradesan ${ }^{2}$ \\ STMIK GI MDP \\ e-mail: ${ }^{1}$ lisa@mdp.ac.id, ${ }^{2}$ iis@ @mdp.ac.id \\ Diajukan: 18 November 2019; Direvisi: 28 November 2019; Diterima: 28 November 2019
}

\begin{abstract}
Abstrak
Salah satu perkembangan teknologi komputer yang banyak dimanfaatkan kegunaannya saat ini adalah Website. Website menjadi salah satu bentuk teknologi yang banyak digunakan karena dapat memberikan kemudahkan dan manfaat bagi penggunanya. Suatu website dapat dikatakan berkualitas apabila apa website tersebut dapat memenuhi kebutuhan atau dapat memberikan kepuasan kepada penggunanya. Penulis menggunakan Metode WebQual 4.0 dengan tiga dimensi utamanya yaitu usability, information, service interaction untuk mengukur kualitas layanan yang dapat dikaitkan dengan kepuasan pengguna. Penelitian ini dilakukan pada pengguna website di Universitas XYZ. Metode yang digunakan dalam penelitian ini adalah regresi linier berganda. Hasil pengujian menyatakan bahwa variabel independen (usability, information, dan service interaction ) berpengaruh secara parsial terhadap variabel dependen (kepuasan pengguna) dengan nilai signifikansi dari setiap variabel usability, information, dan service interaction masing-masing sebesar 0,003, 0,000 dan 0,047.
\end{abstract}

Kata kunci: WebQual, Kepuasan pengguna, Website.

\begin{abstract}
One of the developments in computer technology that is widely used today is the Website. Website is one form of technology that is widely used because it can provide convenience and benefits for its users. A website can be said of quality if what the website can meet the needs or can provide satisfaction to its users. The author uses WebQual 4.0 Method with three main dimensions, namely usability, information, service interaction to measure service quality that can be associated with user satisfaction. This research was conducted on website users at XYZ University. The method used in this research is multiple linear regression. The test results state that the independent variables (usability, information and service interaction) partially influence the dependent variable (user satisfaction) with a significance value of each of usability, information and service interaction variables of 0.003, 0.000 and 0.047.
\end{abstract}

Keywords: WebQual, User satisfaction, Website.

\section{Pendahuluan}

Teknologi merupakan hal yang sangat penting dalam menjalankan kegiatan di berbagai aspek kehidupan saat ini. Perkembangan teknologi komputer merupakan salah satu perkembangan teknologi yang berkembang sangat pesat yang dapat memberikan banyak manfaat bagi para penggunanya seperti kemudahan dalam mengolah dan menyimpan data, ketepatan dan kecepatan dalam mencari data yang dibutuhkan, memudahkan dalam berinteraksi, kemudahan dalam mencari dan menyebarkan informasi dan masih banyak manfaat lain yang dapat diperoleh.

Teknologi komputer sekarang juga diterapkan dalam perguruan tinggi untuk membantu mengatasi permasalahan yang dihadapi dalam proses kegiatan yang dilakukan. Oleh karena itu Universitas XYZ yang berada di Kota Palembang juga telah memanfaatkan teknologi komputer untuk memudahkan proses kegiatan belajar mengajar dan untuk meningkatkan kualitas layanannya. Dengan diterapkannya layanan website diharapkan proses yang awalnya dilakukan secara manual dapat di pindah ke dalam sistem untuk menyelaraskan proses kegiatan dengan pihak-pihak yang terkait.

Dengan adanya layanan website ini diharapkan dapat menyediakan informasi dan data yang akurat, cepat dan tepat serta dapat menghemat waktu tetapi tetap mempertahankan kualitas 
dan efisiensi dari informasi yang diberikan bagi pengguna yang membutuhkan. Peranan website suatu perguruan tinggi sebenarnya tidak hanya terbatas sebagai media informasi namun juga untuk menyediakan layanan yang dapat memberikan berbagai kemudahan baik bagi anggota civitas akademika maupun calon civitas yang akan bergabung dengan perguruan tinggi tersebut [1]. Kualitas layanan website merupakan barometer yang digunakan untuk mengukur kualitas perguruan tinggi tersebut [2]. Universitas XYZ sejauh ini belum mengetahui apakah layanan website yang diberikan telah memenuhi kepuasan pengguna. Oleh karena itu dilakukan penelitian ini sebagai umpan balik bagi Universitas XYZ dalam upaya perbaikan untuk meningkatkan kepuasan dari pengguna layanan website.

\section{Metode Penelitian}

Metode penelitian yang penulis gunakan adalah metode penelitian deskriptif kuantitatif dengan melakukan penyebaran kuesioner kepada responden yang menggunakan layanan website Universitas XYZ sebagai sumber data agar dapat diperoleh data primer untuk dianalisis. Rancangan kuesioner dilakukan dengan mengacu pada variabel-variabel yang sudah ditentukan. Kemudian penulis melakukan studi literatur untuk mencari teori yang berhubungan dengan masalah yang ada agar model dan variabel penelitian dapat ditentukan. Apabila model dan variabel penelitian telah ditentukan maka sebanyak 92 kuesioner disebarkan pada responden yang dianggap cocok sebagai sumber data. Setelah hasil kuesioner terkumpul kemudian penulis melanjutkan pada tahap selanjutnya yaitu tahap analisis. Analisis data dilakukan dengan melakukan pengujian validitas dan reliabilitas terhadap hasil kuesioner yang telah diperoleh kemudian dilanjutkan dengan melakukan uji analisis regresi untuk. Pengujian ini dilakukan agar diperoleh hasil analisis yang dapat dijadikan pedoman untuk memberikan masukkan terhadap permasalahan yang ada pada universitas XYZ. Tahap akhir dari penelitian ini penulis akan menyimpulkan hasil analisis dan memberikan saran bagi Universitas XYZ.

\subsection{Kuesioner}

Pengumpulan data pada penelitian ini diperoleh dengan kuesioner. Kuesioner merupakan daftar pernyataan tertulis yang telah dirancang sebelumnya dan akan disebarkan ke responden untuk dijawab. Teknik pengumpulan data dengan menggunakan kuesioner merupakan salah satu teknik yang dianggap efisien, selain itu peneliti dapat mengetahui dengan pasti pengukuran variabel yang akan diteliti. Kuesioner yang dibagikan kepada responden berisikan pernyataan-pernyataan, kemudian akan diukur dengan menggunakan Skala Likert dengan penilaian antara setuju sampai tidak setuju terhadap pernyataan yang telah diberikan [3].

\subsection{Populasi}

Populasi merupakan seluruh objek baik itu berupa orang, peristiwa, kejadian, ataupun objek lain yang akan digunakan untuk diteliti. Dalam penelitian ini yang merupakan populasi adalah seluruh pengguna layanan Website Universitas XYZ.

\subsection{Sampel}

Menurut [4] mendefinisikan sampel sebagai sub kelompok atau sebagian dari populasi, di mana sampel terdiri atas sejumlah anggota yang dipilih dari populasi. Pada penelitian ini sampelnya adalah pengguna website Universitas XYZ sebanyak 92 orang. Teknik accidental sampling dipilih dalam penelitian ini di mana teknik ini mengambil sampel kepada responden berdasarkan kebetulan, yaitu responden yang secara tidak sengaja bertemu dengan peneliti dan dianggap memenuhi syarat untuk dijadikan sumber data maka dapat dipilih sebagai responden [5].

\subsection{Webqual (Website Quality)}

Website adalah salah satu bentuk teknologi komunikasi dan publikasi yang telah banyak digunakan pada masa kini. Dikarenakan kemudahan, biaya yang rendah dan jangkauan yang luas menjadikan website populer di manfaatkan dalam kegiatan organisasi. Kepuasan pengguna website perlu menjadi perhatian dari penyedia layanan website di mana kepuasan pengguna akan menjadi ukuran utama dari kualitas website. WebQual merupakan salah satu metode atau teknik yang cukup banyak digunakan pada pengukuran kualitas website berdasarkan persepsi pengguna atau pengunjung [6].

Metode WebQual merupakan metode yang mengalami pengembangan dari metode pengukuran kualitas jasa yang banyak digunakan pada penelitian sebelumnya yaitu metode ServQual yang dirancang oleh Parasuraman [7]. Metode WebQual dalam penyusunan kategori dan butir pernyataannya telah mengalami iterasi. Pada penelitian ini penulis menggunakan versi terbaru dari WebQual yaitu WebQual 4.0 di mana metode ini menggunakan tiga kategori pengukuran dengan 34 butir pertanyaan. Adapun tiga 
kategori yang digunakan untuk pengukurannya adalah usability, information, dan service interaction. Kategori usability didasarkan pada kualitas yang dihubungkan dengan rancangan website, seperti penampilan website, mudah digunakan, posisi, dan tampilan gambar kepada pengguna. Kategori information dilihat dari kualitas informasi yang diberikan kepada pengguna misalnya dilihat dari isi informasi, format, ketepatan informasi dan relevansi yang diberikan dari informasi yang diberikan. Kategori service interaction berhubungan terhadap interaksi layanan yang dirasakan pengguna ketika terlibat secara mendalam dengan website [8].

\subsection{Uji Validitas}

Menurut Sekaran [9], validitas menunjukkan ketepatan dan kecermatan alat ukur dalam melakukan fungsi ukurnya, sehingga dalam penelitian ini penulis menggunakan uji validitas untuk melihat apakah pernyataan kuesioner yang digunakan dalam penelitian ini valid atau tidak. Kriteria pengambilan keputusan dalam penelitian ini dengan melihat perbandingan nilai $r_{\text {hitung }}$ dan $r_{\text {tabel }}$. Apabila nilai $r_{\text {hitung }}<$ nilai $r_{\text {tabel }}$ maka pernyataan kuesioner yang digunakan dalam penelitian ini dinyatakan tidak valid, sedangkan apabila nilai $r_{\text {hitung }}>r_{\text {tabel }}$ maka pernyataan kuesioner yang digunakan dalam penelitian ini dinyatakan valid.

\subsection{Uji Reliabilitas}

Uji Reliabilitas digunakan untuk memastikan apakah pernyataan yang digunakan dalam penelitian ini dapat dipercaya sebagai alat pengumpulan data [10]. Kriteria pengambilan keputusan dalam penelitian ini dilihat dengan menggunakan nilai Cronbach"s Alpha. Apabila nilai Alpha hasil pengujian > 0,6 maka dapat disimpulkan bahwa pernyataan yang digunakan dalam penelitian ini dapat dipercaya atau reliabel, tetapi sebaliknya apabila nilai Alpha hasil pengujian < 0,6 maka dapat disimpulkan bahwa pernyataan yang digunakan dalam penelitian ini tidak dapat dipercaya atau tidak reliabel [11].

\subsection{Uji Asumsi Klasik}

Untuk dapat mendapatkan hasil model regresi yang tidak bias maka dilakukan uji asumsi klasik. Uji asumsi klasik yang dilakukan pada penelitian ini yaitu Multikolinearitas, Heteroskedastisitas, dan Normalitas.

\subsubsection{Multikolinearitas}

Uji multikolinearitas bertujuan untuk menguji apakah antara variabel bebas yang digunakan dalam penelitian ini memiliki korelasi yang tinggi atau tidak. Suatu model uji regresi akan dinyatakan baik apabila tidak terjadi multikolinearitas. Kriteria pengambilan keputusan untuk menentukan terjadi atau tidaknya multikolinearitas dengan nilai tolerance dan nilai VIF hasil uji. Dikatakan tidak terjadi multikolinearitas apabila nilai tolerance hasil uji $>0,10$ dan nilai $\mathrm{VIF}<10$, sebaliknya apabila nilai tolerance hasil uji $<0,10$ dan nilai VIF > 10 maka data yang digunakan dalam penelitian ini disimpulkan terjadi multikolinearitas [3].

\subsubsection{Heterokedastisitas}

Uji Heterokedastisitas dilakukan untuk menunjukkan bahwa varians variabel yang digunakan dalam penelitian ini tidak sama. Model regresi dikatakan baik apabila terjadi kesamaan varians variabel atau dengan kata lain homokedastisitas. Kriteria pengambilan keputusan yang digunakan dalam penelitian ini untuk menentukan terjadi atau tidaknya heterokedastisitas adalah dengan menggunakan tingkat signifikansi sebesar 0,05. Apabila nilai tingkat signifikansi $>0.05$ maka dapat disimpulkan bahwa varians variabel yang digunakan dalam penelitian ini terbebas dari heterokedastisitas, sebaliknya apabila nilai tingkat signifikansi dalam penelitian ini < 0,05 maka dapat disimpulkan bahwa varians variabel dalam penelitian ini terdapat heterokedastisitas [12].

\subsubsection{Normalitas Data}

Pada penelitian ini dilakukan uji normalitas agar diketahui apakah data yang akan dianalisis distribusi normal atau tidak. Suatu model regresi dikatakan baik apabila model regresi terdistribusi normal. Untuk menghindari bias dalam analisis data maka analisis data mensyaratkan data harus terdistribusi normal sehingga data tidak normal tidak dapat digunakan karena dapat menimbulkan bias dalam interpretasi dan dapat mempengaruhi data lainnya.

\subsection{Uji Hipotesis}

Pengujian hipotesis yang akan dilakukan dalam penelitian ini dengan menggunakan Uji F untuk melihat pengaruh variabel independen terhadap variabel dependen secara bersama-sama, dan Uji t untuk 
melihat pengaruh variabel independen terhadap variabel dependen secara parsial. Kriteria pengambilan keputusan yang digunakan dalam penelitian ini adalah tingkat signifikansi sebesar 0.05.

\section{Hasil dan Pembahasan}

\subsection{Validitas}

Untuk mengetahui hasil dari uji validitas maka dilakukan perbandingan antara nilai $r_{\text {hitung }}$ dengan nilai $r_{\text {tabel }}$. Suatu pengujian validitas dapat dikatakan valid apabila nilai $r_{\text {hitung }}>$ dari $r_{\text {tabel }}$, sedangkan dikatakan tidak valid apabila nilai $r_{\text {hitung }}<$ dari $r_{\text {tabel }}$. Dengan signifikansi 0,05 maka di dapat $r_{\text {tabel }}$ sebesar 0,1707. Berikut hasil uji validitas :

Tabel 1. Hasil uji validitas kuesioner.

\begin{tabular}{|c|c|c|c|c|c|}
\hline No & Kode Kuesioner & r hitung & No & Kuesioner Kode & r hitung \\
\hline 1 & $\mathrm{X} 11$ & 0,787 & 18 & X33 & 0,760 \\
\hline 2 & $\mathrm{X} 12$ & 0,778 & 19 & X34 & 0,821 \\
\hline 3 & $\mathrm{X} 13$ & 0,736 & 20 & $\mathrm{X} 35$ & 0,795 \\
\hline 4 & $\mathrm{X} 14$ & 0,766 & 21 & X36 & 0,817 \\
\hline 5 & $\mathrm{X} 15$ & 0,747 & 22 & X37 & 0,720 \\
\hline 6 & $\mathrm{X} 16$ & 0,698 & 23 & Y1 & 0,699 \\
\hline 7 & $\mathrm{X} 17$ & 0,639 & 24 & $\mathrm{Y} 2$ & 0,728 \\
\hline 8 & $\mathrm{X} 18$ & 0,763 & 25 & Y3 & 0,802 \\
\hline 9 & $\mathrm{X} 21$ & 0,748 & 26 & Y4 & 0,749 \\
\hline 10 & $\mathrm{X} 22$ & 0,846 & 27 & Y5 & 0,721 \\
\hline 11 & $\mathrm{X} 23$ & 0,839 & 28 & Y6 & 0,741 \\
\hline 12 & $\mathrm{X} 24$ & 0,662 & 29 & Y7 & 0,703 \\
\hline 13 & $\mathrm{X} 25$ & 0,738 & 30 & Y8 & 0,778 \\
\hline 14 & $\mathrm{X} 26$ & 0,748 & 31 & Y9 & 0,641 \\
\hline 15 & $\mathrm{X} 27$ & 0,805 & 32 & Y10 & 0,474 \\
\hline 16 & X31 & 0,640 & 33 & Y11 & 0,698 \\
\hline 17 & X32 & 0,735 & 34 & Y12 & 0,748 \\
\hline
\end{tabular}

Berdasarkan hasil uji validitas kuesioner di Tabel 1, diperoleh $\mathrm{r}_{\text {hitung }}>\mathrm{r}_{\text {tabel }}$ yang berarti kuesioner sebagai alat ukur dalam penelitian ini dapat dinyatakan valid.

\subsection{Reliabilitas}

Dalam penelitian ini metode Cronbach Alpa di gunakan untuk melakukan pengujian. Apabila nilai Cronbach Alpa yang diperoleh > 0,6 maka dapat disimpulkan bahwa kuesioner tersebut reliabel tetapi sebaliknya jika nilai Cronbach Alpa < 0,6 maka dapat disimpulkan kuesioner yang digunakan dalam penelitian ini tidak reliabel. Hasil pengujian reliabilitas dalam penelitian ini sebagai berikut :

Tabel 2. Hasil uji reliabilitas kuesioner.

\begin{tabular}{cc}
\hline Variabel & Cronbach's Alpha \\
\hline $\mathrm{X} 1$ & 0,875 \\
\hline $\mathrm{X} 2$ & 0,883 \\
\hline $\mathrm{X} 3$ & 0,873 \\
\hline $\mathrm{Y}$ & 0,907 \\
\hline
\end{tabular}

Berdasarkan tabel di atas, menunjukkan bahwa komponen pernyataan dikatakan reliabel, nilai Cronbach's Alpha yang dapat dilihat dari keempat variabel > dari 0,6.

\subsection{Uji Normalitas}

Untuk mengetahui sebaran data pada variabel apakah terdistribusi normal atau tidak maka dilakukan uji normalitas. Dasar pengambilan keputusan dari pengujian ini apabila tingkat signifikansi lebih besar dari 0,05 maka distribusi data dinyatakan memenuhi asumsi normalitas tetapi apabila nilai signifikansi lebih kecil dari 0,05 maka data dinyatakan terdistribusi tidak normal. 
Tabel 3. Hasil uji normalitas.

\begin{tabular}{llr}
\hline \multicolumn{3}{c}{ One-Sample Kolmogorov-Smirnov Test } \\
\hline $\mathrm{N}$ & \multicolumn{2}{c}{ Unstandardized Residual } \\
\hline Normal Parameters ${ }^{\mathrm{a}, \mathrm{b}}$ & Mean & 92 \\
\cline { 2 - 3 } & Std. Deviation &, 0000000 \\
\hline Most Extreme Differences & Absolute & 2,75271094 \\
\cline { 2 - 3 } & Positive &, 059 \\
\cline { 2 - 3 } & Negative &, 059 \\
\hline Test Statistic & &,- 055 \\
\hline Asymp. Sig. (2-tailed) &, 059 \\
\hline a. Test distribution is Normal. &, $200^{\mathrm{c}, \mathrm{d}}$ \\
\hline b. Calculated from data. & \\
\hline c. Lilliefors Significance Correction. & \\
\hline d. This is a lower bound of the true significance. & \\
\hline
\end{tabular}

Berdasarkan Tabel 3 di atas, hasil pengujian menunjukkan bahwa sebaran data terdistribusi normal, hal ini dapat dilihat dari nilai signifikansi $>0,05$ yaitu 0.200 .

\subsection{Uji Multikolinearitas}

Uji multikolinearitas bertujuan untuk menguji apakah antara variabel bebas yang digunakan dalam penelitian ini memiliki korelasi yang tinggi atau tidak. Dasar pengambilan keputusan pada uji multikolinearitas yang digunakan apabila nilai tolerance $>0.01$ dan $\mathrm{VIF}<0,10$ maka artinya variabel yang digunakan dalam penelitian ini tidak terjadi multikolinearitas. Sebaliknya apabila nilai tolerance $<0.01$ dan VIF > 10 dapat disimpulkan bahwa variabel dalam penelitian ini terjadi multikolinearitas.

Tabel 4. Hasil uji multikolinearitas.

\begin{tabular}{lcc}
\hline \multirow{2}{*}{ Model } & \multicolumn{2}{c}{ Collinearity Statistics } \\
\cline { 2 - 3 } & Tolerance & VIF \\
\hline Usability & 0,203 & 4,936 \\
\hline Information & 0,268 & 3,727 \\
\hline Service Interaction & 0,335 & 2,986 \\
\hline
\end{tabular}

Dari Tabel 4 dapat dilihat bahwa nilai tolerance dan VIF $>0,10$, maka dari hasil pengujian ini dapat disimpulkan tidak terjadi multikolinearitas dalam model regresi.

\subsection{Uji Heteroskedastisitas}

Uji hetereoskedastisitas bertujuan untuk melihat bahwa dalam penelitian ini tidak terjadi kesamaan varians dari residual. Dasar pengambilan keputusan dikatakan tidak terjadi gejala Heteroskedastisitas apabila nilai sig. > 0,05.

Tabel 5. Hasil uji heteroskedastisitas.

\begin{tabular}{|c|c|c|c|c|c|c|}
\hline \multicolumn{7}{|c|}{ Coefficients $^{\mathrm{a}}$} \\
\hline & \multirow{2}{*}{ Model } & \multicolumn{2}{|c|}{ Unstandardized Coefficients } & \multirow{2}{*}{$\begin{array}{c}\text { Standardized Coefficients } \\
\text { Beta } \\
\end{array}$} & \multirow{2}{*}{$\mathbf{t}$} & \multirow{2}{*}{ Sig. } \\
\hline & & $\mathrm{B}$ & Std. Error & & & \\
\hline \multirow[t]{4}{*}{1} & (Constant) & ,751 & 1,166 & & ,644 & ,521 \\
\hline & Usability &,- 190 &, 102 &,- 422 & $-1,852$ & 067 \\
\hline & Information &, 144 & ,092 & ,309 & 1,563 &, 122 \\
\hline & Service Interaction & 139 &, 081 & 304 & 1,715 &, 090 \\
\hline
\end{tabular}

a. Dependent Variable: Abs_Res1

Dari hasil pengujian yang tertera pada Tabel 5 di atas, maka dapat dilihat bahwa tidak ada gejala heteroskedastisitas karena sig $>0,05$ dari ketiga variable tersebut yakni variabel usability, information, dan service interaction sebesar 0,067, 0,122 dan 0.090 .

\subsection{Analisis Pengaruh}

3.6.1. Uji $F$

Uji F dilakukan untuk mengetahui variabel bebas berpengaruh terhadap variabel terikat secara bersama-sama. Kriteria pengambilan keputusan dengan menggunakan nilai tingkat signifikansi sebesar 0,05 . Apabila tingkat signifikansi hasil uji $<0,05$, disimpulkan variabel bebas berpengaruh terhadap 
variabel terikat secara bersama-sama. Tetapi, apabila tingkat signifikansi hasil uji > 0,05 disimpulkan bahwa variabel bebas tidak berpengaruh terhadap variabel terikat secara bersama-sama.

Tabel 6. Hasil uji F.

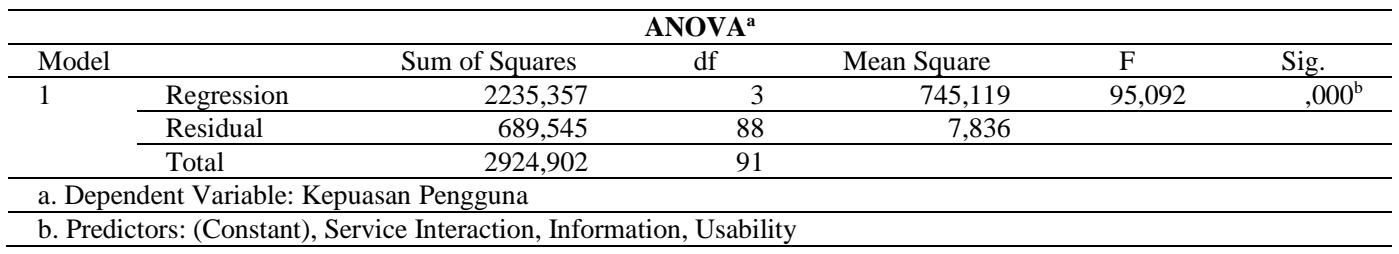

Dari hasil pengujian pada Tabel 6, dapat diketahui tingkat signifikansi pengujian sebesar 0,000< dari 0,05. Hasil pengujian menunjukkan bahwa secara simultan, variabel usability, information, dan service interaction berpengaruh secara signifikan terhadap variabel kepuasan pengguna dalam hal penggunaan website di Universitas XYZ.

\subsubsection{Uji t}

Untuk menguji pengaruh masing-masing variabel bebas terhadap variabel terikat secara parsial maka dilakukan uji t. Tingkat signifikansi dijadikan dasar pengambilan keputusan dalam penelitian ini. Apabila tingkat signifikansi $<0,05$, maka dapat disimpulkan bahwa antara variabel bebas terhadap variabel terikat berpengaruh secara parsial, tetapi apabila tingkat signifikansi > 0,05, maka dapat disimpulkan antara masing-masing variabel bebas terhadap variabel terikat tidak berpengaruh secara signifikan.

Tabel 7. Hasil uji t.

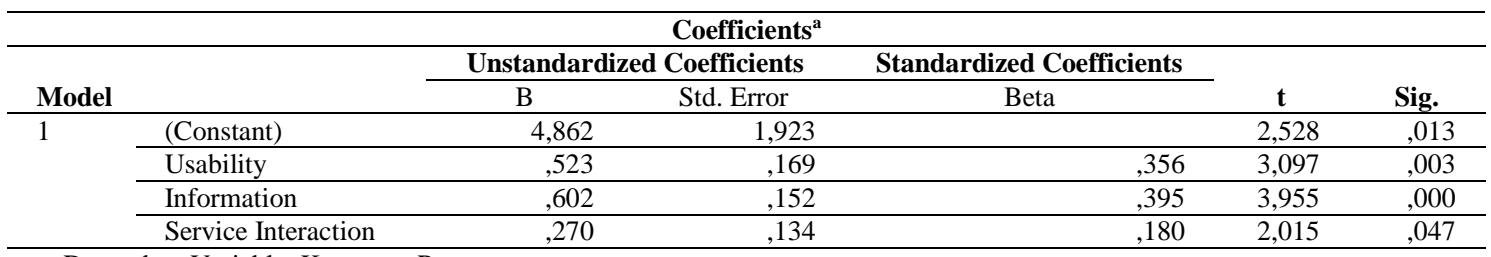

a. Dependent Variable: Kepuasan Pengguna

Dari Tabel 7 di atas, didapatkan nilai signifikansi dari setiap variabel usability, information, dan service interaction masing-masing sebesar : 0,003, 0,000 dan 0,047, hal ini menunjukkan ketiga variabel bebas memiliki tingkat signifikansi $<0.05$, sehingga dapat disimpulkan bahwa ketiga variabel berpengaruh terhadap kepuasan pengguna secara parsial.

\section{Kesimpulan}

Berdasarkan hasil analisis kualitas layanan website Universitas XYZ dengan menggunakan metode WebQual 4.0, maka dapat ditarik kesimpulan bahwa kualitas layanan website Universitas XYZ dengan variabel penelitian usability, information dan service interaction mempengaruhi kepuasan pengguna secara signifikan. Dari pengujian yang dilakukan variabel information yang memberikan kepuasan yang paling tinggi terhadap kepuasan pengguna. Hasil dari penilaian website Universitas XYZ ini diharapkan dapat dijadikan umpan balik sebagai bahan evaluasi pengembangan dan perbaikan terhadap website Universitas XYZ ke depannya terutama pada variabel service interaction yang memperoleh nilai lebih rendah dibanding dua variabel lainnya.

\section{Daftar Pustaka}

[1] D. P. Kesuma, "Analisis Pengukuran Kualitas Layanan Web Perguruan Tinggi XYZ Menggunakan Servqual,” Seminar Nasional Informatika, vol. 1, no. -, pp. 178-183, 2014.

[2] D. Puspitasari, B. P. Widyobroto dan Sumiyana, "Kajian Kepuasan Pelanggan Webiste Universitas Airlangga,", -, Vol. \%1 dari \%2-, no. -, pp. -, 2013.

[3] A. Aditiya, Analisis Pengaruh Kualitas Website Terhadap Kepuasan Pengguna Berdasarkan Metode Webqual 4.0 pada Website www.wingscorp.com, Surabaya: STIKOM Surabaya, 2017.

[4] U. Sekaran, Research Methods for Business, Jakarta: Salemba Empat, 2006.

[5] Sugiono, Metode Penelitian Kuantitatif, Kualitatif dan R\&D, Bandung: PT Alfabet, 2016. 
[6] C. Irawan, "Evaluasi Kualitas Website Pemerintah Daerah Dengan Menggunakan WebQual (Studi Kasus Pada Kabupaten Ogan Ilir),” Jurnal Sistem Informasi (JSI), vol. 4, no. -, pp. 488-502, 2012.

[7] D. B. Napitupulu, "Evaluasi kualitas website universitas XYZ dengan pendekatan Webqual," Buletin Pos dan Telekomunikasi, vol. 14, no. no.1, pp. 51-64, 2016.

[8] S. J. Barnes dan R. Vidgen, "An Integrative Approach to the Assessment of E-Commerce Quality," Journal of Electronic Commerce Research, vol. 3, no. -, pp. 114-127, 2002.

[9] U. Sekaran, Research Methods for Business: A Skill-Building Approach, New York: John Wiley \& Sons, Inc., 2003.

[10] L. A. S. Waloyo, "Mengukur Kualitas Webiste Universitas Dengan Pendekatan Webqual (Studi Kasus : Unika Widya mandala Madiun)," dalam Prosiding Seminar Nasional Sains dan Teknologi Ke-9 Fakultas Teknik Univeristas Wahid Hasyim, Semarang, 2018.

[11] Sugiono, Metode Penelitian Bisnis, Bandung: Alfabeta, 2003.

[12] R. Rusniantoro, A. Kusyanti dan A. Rachmadi, “Analisis Kualitas Layanan Website XYZ Terhadap Kepuasan Pelanggan," Jurnal Pengembangan Teknologi Informasi dan Ilmu Komputer, vol. 2, no. No.6, pp. 2150-2157, 2018. 